\title{
YORKSHIRE FOG AS A PASTURE GRASS
}

\author{
W. A. JACQUES, Senior Lecturer in Field Husbandry, Massey \\ College
}

Yorkshire fog probably has its centre of origin in the Iberian Peninsula, but as a result of continued colonisation since the end of the ice age is now found throughout Europe and North-west Africa. Under the influence of human pastoral activities the species has spread to all the more recently developed farming areas in the temperate regions of the Americas, South Africa, and Australasia.

It is widely represented in pastures of diverse type in New Zealand and particularly in those communities which are typical of the more humid and less fertile regions. It is a major constituent of many of the North Island hill country swards where declining fertility has led to the dominance of browntop (Agrostis tenuis) and Danthonia pilosqand contributes in no small measure to the total production of many lowland dairy pastures, and particularly so in the Waikato.

If Yorkshire fog is found to be worth using, the hill country is the logical place for its utilisation for only one quarter of the surface of New Zealand is below the $650 \mathrm{ft}$ contour. Topography is rugged and 28 million acres or 64 per cent of the farming land available is said to be too steep to permit of mechanical cultivation. Recent changes in management of hill country have highlighted a hidden potential particularly in the North Island and this should be explored even to the point of breeding grasses specifically for this environment. Yorkshire fog is one of the grasses which offers the greatest promise and to this end breeding of a synthetic strain has been started at Massey College.

\section{BASIS FOR SELECTION}

\section{Climatic Tolerance}

Yorkshire fog exhibits a wide tolerance of temperature regimes. Growth of foliage in controlled environmental studies conducted by Mitchell at Grasslands has been in general similar to that of perennial ryegrass, cocksfoot. and browntop. The rate of growth remained high at temperatures between 55 and 85 degrees $F$ and it was intermediate between perennial ryegrass and cocksfoot in its high temperature tolerance. Production is curtailed in winter but even so it is remarkably constant throughout the year relative to many other widely used and better regarded species. 


\section{Edaphic Tolerance}

This grass shows an almost complete absence of edaphic specialisation and is little affected by $\mathrm{pH}$. Its moisture requirements however are rather more specific. It becomes aggressive only where the rainfall is relatively high (35 in. or more per annum) or where the soil moisture content is adequate (as in most peat soils).

The absence of edaphic specialisation may account for its very wide distribution but the exact physiological basis for it is not clear. It has been suggested by Mouat, Walker, and Jackman after studying the cation exchange capacity of the root systems of various grasses and clovers, that Yorkshire fog has a high competitive ability for phosphate, nitrogen and potash where their deficiency is a factor limiting the growth of plants of higher ecological succession. The true significance of endophytic mycorrhiza infecting the root and the anatomy of the root system are not known, but they could facilitate nitrogen nutrition and the uptake of nutrients when the soil water level is high.

\section{Biotic Tolerance}

Though Yorkshire fog will persist under a wide range of management regimes it favours a lenient system of grazing. Here again this grass lies between perennial ryegrass and cocksfoot. The preponderant prostrate habit does little to mitigate the ill effects of heavy grazing.

In the sward, growth of fog is centred on leaf expansion on a moderate number of larger tillers whereas in ryegrass and browntop it is centred on a large number of small tillers. These large tillers together with lack of strengthening tissue in the leaves and the elevation of the growing point above ground make Yorkshire fog susceptible to trampling damage.

\section{Diseases and Pests}

The most troublesome is rust (Puccinia coronata) which though it does not kill the attacked plant it does reduce palatability and yield. There is considerable variation from plant to plant and in general the prostrate plants as a group arc more prone to heavier infection than the erect forms. Along with certain other plants, Yorkshire fog is the host of the fungus Pithomyces chartarum which in some seasons causes the photosensitisation and liver damage to (mainly) sheep, known to the farmer as facial eczema.

Occasionally mortality of plants in early summer may be high or locally complete due to damage or death of the growing points through Argentine stem weevil (Hyperodes bonariensis) . No other serious disease or pest has been found. 


\section{PALATABILITY}

Yorkshire fog (though called sweetgrass in Chile) is not a palatable grass in a relative sense. It is often neglected by stock in preference to other species when free choice and ample grazing are available. Lack of palatability has often been attributed to pubescence. If this is so, an improvement should be possible by selection, for considerable variation exists between plants from the same source and also on a regional basis. A truly glabrous (hairless) form has not been found.

Studies on the grazing preferences of sheep on spaced plant material show that preferences and growth form are closely linked; the extremely prostrate, agronomically undesirable ones are the least palatable.

There is a low proportion of both strengthening tissue and collateral vascular bundles in the leaves and theoretically the feeding value should be high, but comparative chemical analyses give no clue as to any differences in feeding value between Yorkshire fog and perennial ryegrass.

FIG. 1:

Breaking Strain on the Leaves of Four Grasses

\begin{tabular}{llrrr}
\hline \multicolumn{1}{c}{ Species } & & Oldest Leaf & Middle Leaf Youngest Leaf \\
\hline Perennial Ryegrass & $\ldots$ & $36.4 \pm 1.7$ & $43.9 \pm 2.5$ & $38.5 \pm 3.2$ \\
Long Rotation & $\ldots .-$ & $29.8 \pm 1.9$ & $31.8 \pm 2.1$ & $26.6 \pm 2.0$ \\
Short Rotation ...- & $\ldots .$. & $25.3 \pm 1.8$ & $28.3 \pm 2.6$ & $17.7 \pm 1.5$ \\
Yorkshire fog .. & .- & $8.7 \pm 0.7$ & $7.2 \pm 0.8$ & $5.5 \pm 0.6$ \\
\hline
\end{tabular}

load at moment of failure (gms)

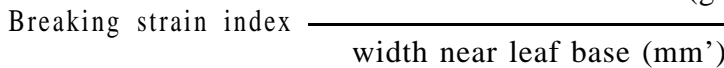

The main problem with this grass then lies not in its feeding value but rather its palatability and grazability.

\section{UTILISATION OF ECOTYPIC VARIATION}

Despite the relatively recent development of New Zealand's grassland, considerable ecotypic development has been shown to occur in the major out-breeding species-ryegrass, cocksfoot, timothy. Yorkshire fog shows comparable development. As in Europe, the variation pattern strongly reflects the recurrence of certain climatic, biotic and edaphic sequences, each characteristic being closely associated with the length of the active growing period, the temperature regime, the incidence of seasonal moisture stress and the influence of the grazing animal. In New Zealand, natural selection has taken place to such an extent that variability is seen to be following that found in the centre of origin (Europe) ; 


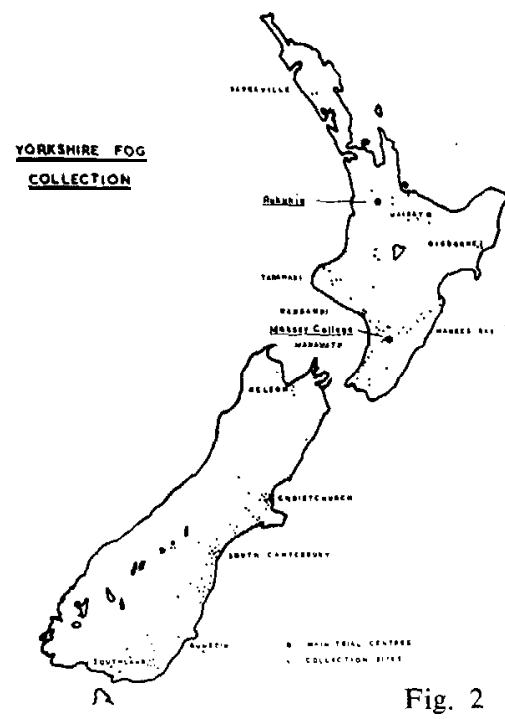

New Zealand has in fact become a new centre of diversity of this species.

In 1954, 151 seed samples were received from the areas shown in Fig. 2. Their coverage was not complete in that no samples were sent from Westland and only two from Northland.

From the seed we got 4,214 spaced plants, and these when classified on a regional basis gave some interesting relationships. Two climatic factors were shown to be paramount, viz. temperature and moisture.

The length of the growing season is under thermal control and is considered to be the number of months in which evapotranspiration is in excess of 1 in.; this is shown in Fig. 3.

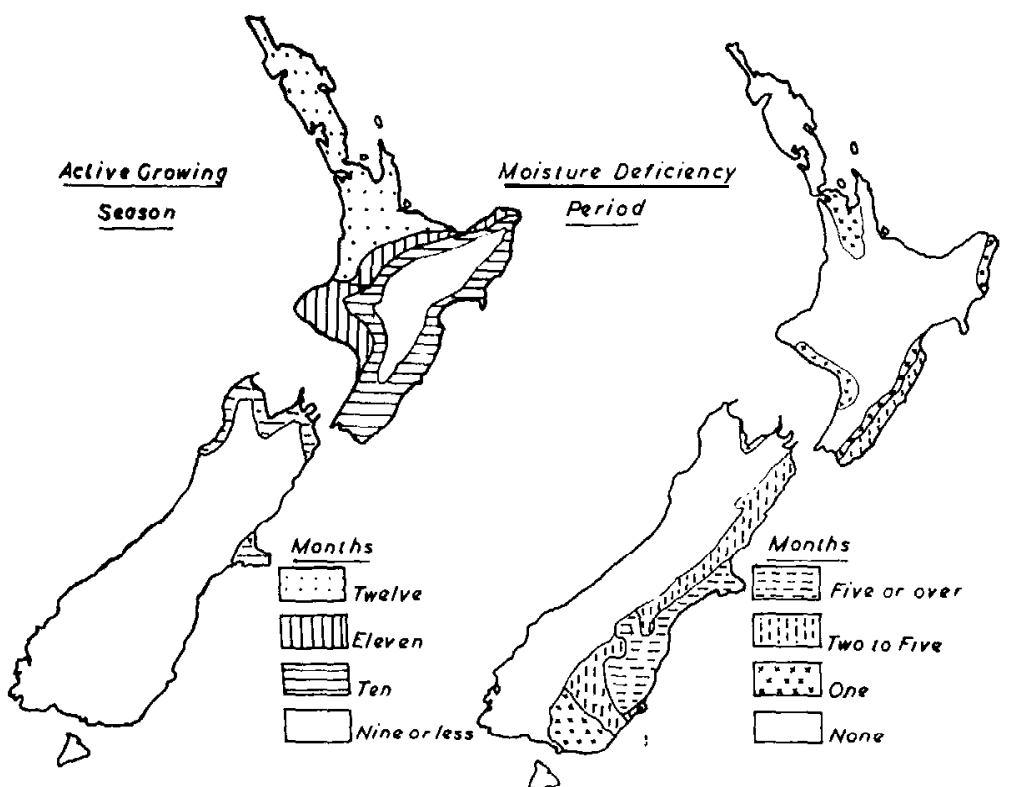

Fig. 3: Left-Number of months in which evapotranspiration is in excess of 1 in. Right-The moisture deficiency is confined almost solely to the East Coast regions. 
On the other hand the control of evapotranspiration by moisture governs the amount of growth during the warmer months. Moisture deficiency is based for the purpose of this paper on the exhaustion of the soil reserves estimated at $1 \mathrm{in}$. of rainfall. The deficiency is confined almost solely to the East Coast regions as shown in Fig, 3.

Winter temperatures are most severe in the South Island. South of the 45 degrees $F$ isotherm there is little winter growth of Yorkshire fog, but between 45 and 50 degrees $F$ there is a moderate growth and above the $\mathrm{SO}$ degrees $\mathrm{F}$ isotherm the growth is relatively high. The percentage of plants which flowered in the first year when spring sown was highest from districts where winter temperatures were highest and lowest where they were most severe. Fig. 4.

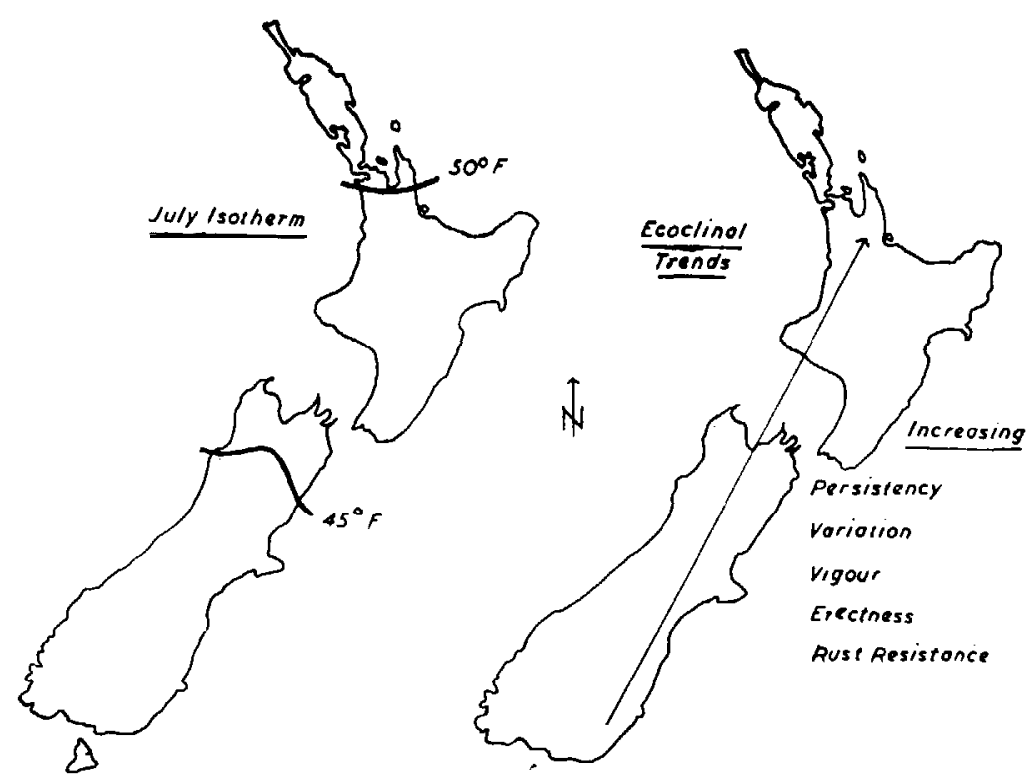

Fig. 4

The ecoclinal trends from south (cold) to north (warm) are shown in Fig. 4. To the north there is an increasing degree of persistency, vigour, resistance to rust, and also variation in growth type, with erect and semi-erect forms assuming greater importance as against prostrate and semi-prostrate forms further south. 
REGIONAL CHARACTERISTICS.

\begin{tabular}{|c|c|c|c|c|c|c|c|c|c|}
\hline \multirow{2}{*}{$\begin{array}{l}\text { CLIMATIC } \\
\text { REGION }\end{array}$} & \multirow{2}{*}{ 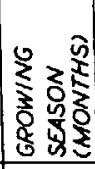 } & \multirow{2}{*}{ 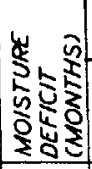 } & \multicolumn{2}{|c|}{ GROWTH F } & \multicolumn{2}{|c|}{ FORM $\%$} & \multicolumn{2}{|c|}{ FLOWERINC } & \multirow{2}{*}{ 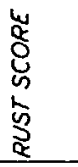 } \\
\hline & & & $\begin{array}{l}\hat{u} \\
\text { 芯 } \\
\end{array}$ & 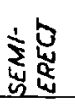 & 齐 & $\begin{array}{l}\frac{2}{5} \\
0 \\
8\end{array}$ & क्ष & $\begin{array}{l}t \\
z^{5} \\
5\end{array}$ & \\
\hline WAIKATO-BP & $11-12$ & $0-1$ & 6 & 13 & 29 & 52 & 80 & 65 & 3.89 \\
\hline TARANAKI & 11 & 0 & 5 & 14 & 31 & 50 & 75 & 36 & 3.93 \\
\hline WANGANUI & 11 & 1 & 4 & 10 & 21 & 65 & 33 & 36 & 4.52 \\
\hline MANAWATU & 11 & 3 & 7 & 14 & 36 & 43 & 10 & 34 & 3.37 \\
\hline GISBORNE & 11 & $1-2$ & 2 & 13 & 25 & 60 & 50 & 68 & 3.91 \\
\hline HAWKES BAY & 10 & $1-4$ & 2 & 10 & 22 & 66 & 44 & 24 & 4.40 \\
\hline NELSON & $9-10$ & $1-2$ & 1 & 5 & 29 & 65 & 33 & 83 & $4 \cdot 28$ \\
\hline CHRISTCHURCh & 10 & $2-5$ & 1 & 4 & 17 & 78 & 14 & 85 & 4.57 \\
\hline S.CANTERBURY & 9 & $2-5$ & 으 & 3 & 28 & 69 & 10 & 46 & $4 \cdot 65$ \\
\hline DUNEDIN & 9 & 2 & 0 & 2 & 33 & 65 & 0 & 37 & 4. 67 \\
\hline b.SOUTHLAND & 9 & 0 & 0 & 5 & 30 & 65 & 0 & 47 & 4.62 \\
\hline
\end{tabular}

tAercentoge of plonts flowering before NOV. 22nd in the second seoson.

Fig. 5

These ecoclinal trends are shown in Fig. 5. It is expected that the trends will be still more marked in Northland.

\section{VARIATION IN GROWTH FORM}

FIG. 6

\begin{tabular}{|c|c|c|c|c|c|}
\hline Leaf Form & Erect & $\begin{array}{r}\text { Plant } \\
\text { Semi-Erect }\end{array}$ & $\begin{array}{l}\text { Growth } \\
\text { Semi- } \\
\text { Prostrate }\end{array}$ & $\begin{array}{l}\text { Form } \\
\text { Prostrate }\end{array}$ & Totals \\
\hline Broad (flat) $\quad \ldots$ & 21 & 36 & 293 & 629 & 979 \\
\hline Medium (flat) & 125 & 3.50 & 620 & 9.51 & 2,046 \\
\hline Narrow (flat) & 22 & 44 & 178 & 284 & 528 \\
\hline Broad (rolled) .... & - & $\rightarrow$ & 8 & 84 & 92 \\
\hline Medium (rolled) & 1 & 14 & 108 & 340 & 463 \\
\hline Narrow (rolled) .... & 一 & 5 & 29 & 72 & 106 \\
\hline T O T A L S ....... & 169 & 449 & 1,236 & 2,360 & 4,214 \\
\hline
\end{tabular}

Of all the plants under test 4 per cent were erect, I I per cent semi-erect, 29 per cent semi-prostrate and 56 per cent prostrate. 


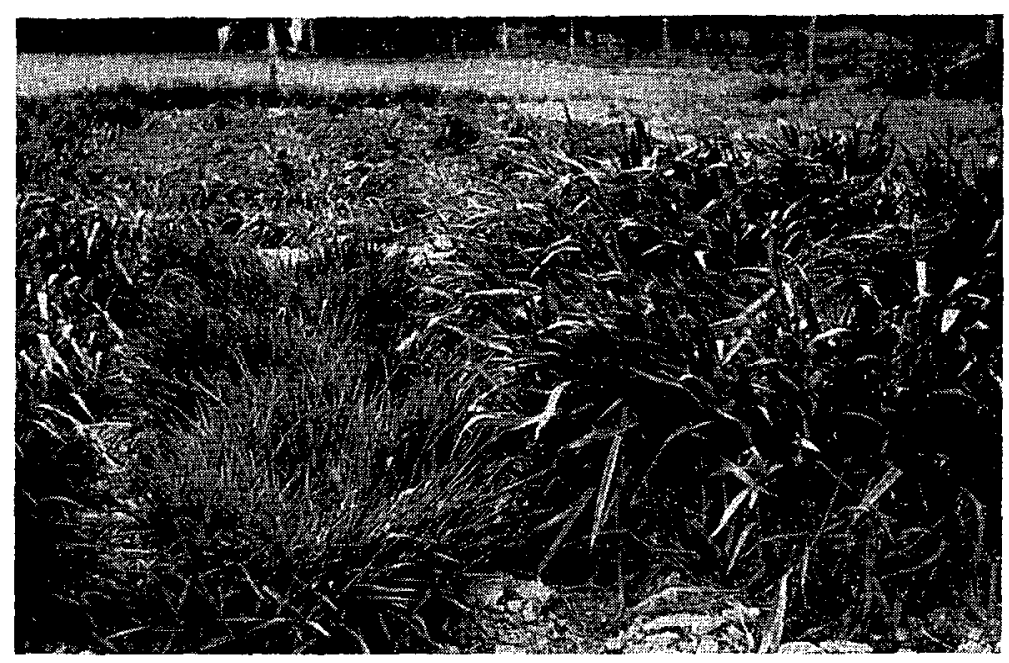

Fig. 7: The broad and narrow leaved forms indicate the wide range that can occur.

Fig. S-Erect and prostrate broad leaved forms.

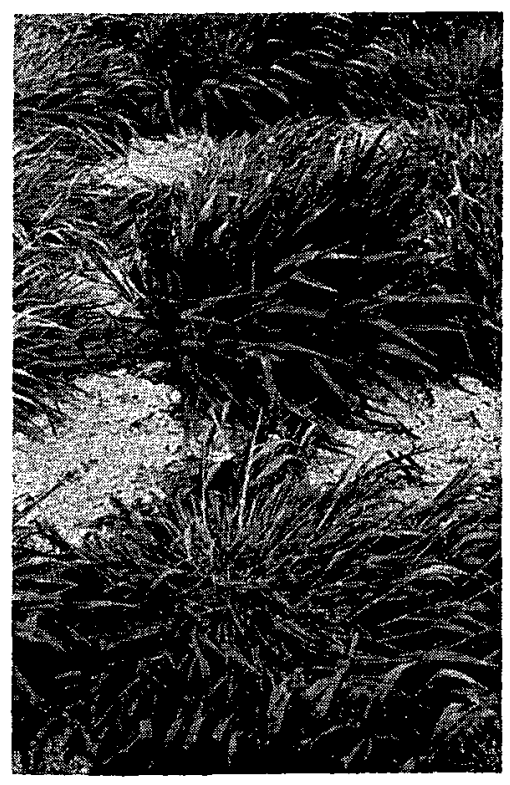




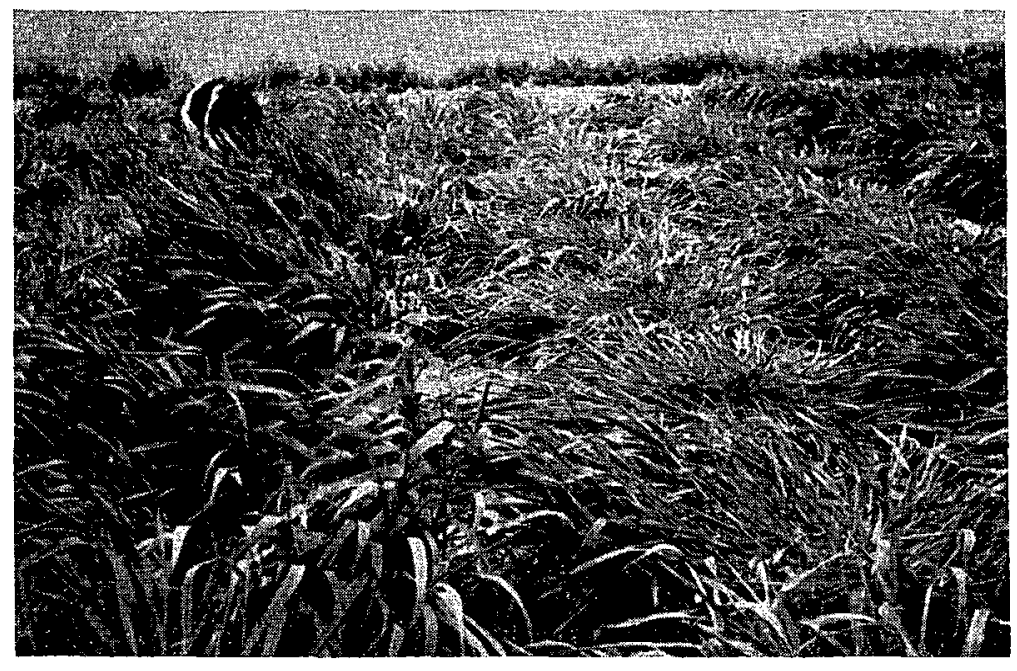

Fig. 9-Broad erect and medium broad leaved forms.

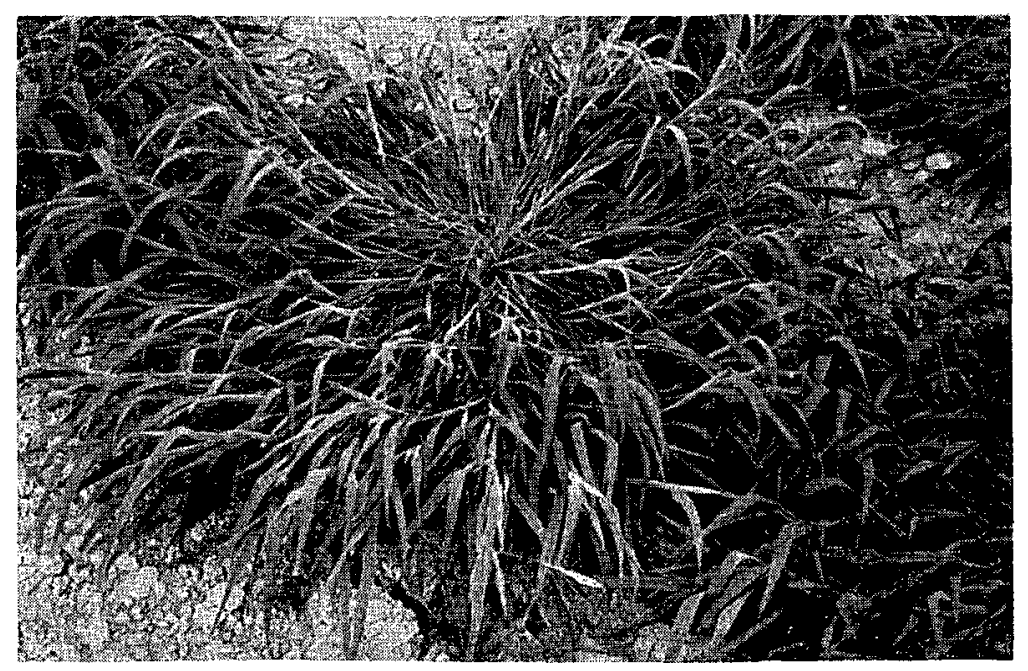

Fig. 10: Semi-prostrate form just prior to flowering. 


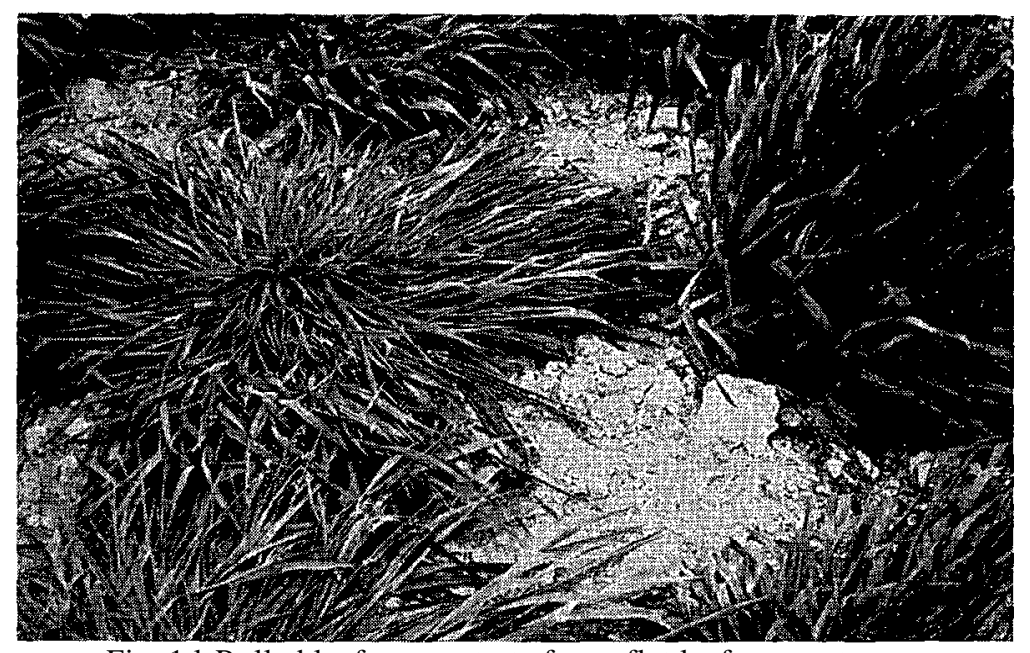

Fig. 1 1-Rolled leaf on prostrate form, flat leaf on erect one.

\section{Relative Yields}

FIG. 12:

(Grazed): Total D.M. Production (Ib) August 1961-September 1962

\begin{tabular}{|c|c|c|c|c|c|}
\hline Species & & Total yield & Grass & Clover & Weeds \\
\hline Perennial Ryegrass & & 9,300 & 7,700 & 1,050 & 550 \\
\hline Long Rotation & ... & 10,100 & 8,900 & 650 & 550 \\
\hline Short Rotation .... & & 9,600 & 7,750 & 1,270 & 580 \\
\hline Bred Yorkshire fog & .... & 10,300 & 8,200 & 1,500 & 600 \\
\hline
\end{tabular}

The high yields of Yorkshire fog were surprising. In trials carried out by Robinson at Massey under a system of grazing with sheep, Yorkshire fog gave a higher total yield than any of the three ryegrasses and the pasture had an excellent clover balance. Watkin in trials at Lincoln substation with commercial seed got results from grazing even better than these; Yorkshire fog outyielded perennial ryegrass and cocksfoot and was second to $\mathrm{S} 170$ tall fescue.

FIG. 13:

\begin{tabular}{|c|c|c|c|c|c|c|}
\hline (M own): & Total & D.M & Production & August & 1960.August & 1961 \\
\hline Species & & & Total yield & Grass & Clover & Weeds \\
\hline \multicolumn{3}{|c|}{ Perennial Ryegrass } & 13,603 & 6,921 & 5,984 & 700 \\
\hline \multicolumn{2}{|c|}{ Short Rotation } & & 12,191 & 6,926 & 4,541 & 724 \\
\hline \multirow{2}{*}{\multicolumn{3}{|c|}{$\begin{array}{l}\text { Bred Yorkshire fog } \\
\text { Comm Yorkshire fog }\end{array}$}} & 12,794 & 10,756 & 1,871 & 167 \\
\hline & & & 12,837 & 6,773 & 2,716 & 3,348 \\
\hline \multirow{2}{*}{$\begin{array}{l}\text { Prairie grass } \\
\text { Cocksfoot }\end{array}$} & $\therefore 0$ & - & 12,135 & 2,998 & 7,011 & 2,128 \\
\hline & $\ldots$ & & 14,686 & 12,143 & 2,018 & 525 \\
\hline \multicolumn{3}{|l|}{ Timothy } & 12,272 & 4,831 & 5,902 & 1,539 \\
\hline
\end{tabular}


Fig. 13 gives the relative yields from mowing trials over I2 months in the second year of production. It shows firstly that selected Yorkshire fog (32 polycrossed plants) is an improvement on the unselected sample and that Yorkshire fog is highly productive under a lenient mowing system.

\section{SUMMARY}

The most suitable gene source was found to be located in the North Island, especially in Manawatu, Waikato, Taranaki, and Wanganui. Populations from these regions exhibited persistency, sustained vigour throughout the year, and less severe infection from rust. Plants from the drier eastern areas in the North Island and from the arable areas of the South Island were frequently short lived and displayed tendencies towards the undesirable features of extreme prostrate growth, prolific head production, and strongly pubescent foliage and none of them featured in the selections.

In view of the decided north-south ecoclinal trends it is possible that a highly suitable gene source for high production will be found in Northland. Unfortunately an insufficient number of seed samples was received from this region for the original test for this to be proved, but observations otherwise have raised the hope that an erect-growing, broad-leaved, rust-resisting, high winteryielding and high annual-yielding synthetic strain can be developed from this source. This strain should in theory be more palatable, as pubescence is less than on forms that have developed further south. If or when the existence of this superior gene source is established, it will be possible to develop further synthetics rapidly. 


\section{BIBLIOG RAPHY}

Basnyat, N. B. ((1957): Unpublished thesis.

Beddows, A. R. (1961): J.Ecol.49 421-430.

Bocher, T. W. and K. Larsen (1958): Bot. Notiser 11 I. 289.

Edmond (1961): Personal communication.

Hileendorf, F. W. (193.5): Bull. N.Z. Deo. Sci. Industr. Res. 47.

Hulten, E. (1950): Atlas of the Distribution of Vascular Plants in N.W.

Europe. Stockholm: Generalstobens Lithografiska Anstalts Forlag.

Jackman, R. H. (1960): Sheep Farming Annual. Massey College. 75.

Madden, E. A. (1940) : Bull. N.Z. Dep. Sci. Industr. Res. 79.

McMeekan, C. P. (1960): Grass to Milk. Wellington: N.Z. Dairy Expr.

Mitchell, K. J. ( 1959) : Proc N.Z. Grassl Ass. 21st Conf. 108.

Mouat, M. C. H. and Walker T. W. (1959) : Plant \& Soil 11. 41.

Munro, J. M. M. (1961) : Unpublished thesis. Massey College.

Nicholson, T. H. ( 1960) : Trans Brit. mycol. Soc. 43132.

Robinson, G. S. (1962): Personal communication.

Soper, K. (1959): N.Z.J. Acric. Res. 2329.

Vinall. H. N. and M. A. Hein (1937): Breeding Miscellaneous Grasses Agric. Yearb. U.S. Dep. Agric. p. 1032.

Watkin, B. R. (1960): Unpublished data. Grasslands Div., D.S.I.R., N.Z.

\section{DISCUSSION}

Comment (E. Madden): Although Yorkshire foe mav not be highly reearded for its 'palatability' it is a valuable contributor at most seasons to the pastures on the hill country. If Mr Jacques and his associates can produce a selected strain of Yorkshire fog, the farmers in the hill country would be able to increase their carrying capacity and the weed population and inferior grasses would be reduced.

Q. (Prof. Langer): By concentrating your breeding material on North Island types are you limiting the adaptability of your plant material, and is it likely to be suitable to the more rigorous climate one might find in the South Island hill country?

A. In view of the very high degree of diversity that one finds, there would not be much danger of this. Through the courtesy of Mr Madden I have had plants from the highest part of the Desert Road, 4,600 ft, and they are now doing very well. I think we could use these types satisfactorily.

Q. (G. Thorpe): Is not the true place of Yorkshire fog in the transitional or fertility building phases of development, and is this grass likely to stand up to the hard grazing it will probably get?

A. I think if it were combined with other species (it should not be used as the only grass) the damage could be buffered to some extent by the other species, provided there was a reasonable period between grazings. On the hill country you wouldn't get the intensity of stocking that you get in the Waikato, and yet in the Waikato it provides at least 50 per cent of the butterfat.

Q. (L. Bascand): Were the yields of D.M. shown by you and Mr Robinson obtained from the prostrate types or the erect types? 
A. The selection used for that trial consisted of eight plants and of those, two were erect, and the remainder semi-erect or semi-prostrate; there were no completely prostrate plants.

Q. You say that Yorkshire fog becomes aggressive where the soil moisture is adequate, as in most peat soils. I've always thought that the special feature of Yorkshire fog was its capacity to stand up to dry conditions because it runs so rapidly to seed, and these are the conditions one gets in peat soils, they appear to be moist but they go through periods of extreme dryness, and it is because of the capacity of the plant to run to seed that it is so persistent in this type of soil.

A. When we first made our selections we found that a lot of the dry area plants from the South Island were short lived and the amount of seed produced was out of all proportion to that of plants from other sources. I think if you follow the ecoclinal trend and go north to the Waikato and North Auckland you will find that Yorkshire fog will tolerate at least the dryness that one associates with the normal hill country of the North Island. I would not expect to find it growing on the badly overdrained peat soils.

Comment: Stock grazing on a pasture that is dominantly Yorkshire fog show a tendency to scour, but when these pastures are substituted by what we commonly call better species, scouring tends to stop.

A. I would like to know more about this problem before I give full comment. Yorkshire fog is a common constituent in pastures on peat, and peat is notoriously copper deficient. Was this pasture on peat?

Comment: No, it was pumice country.

Q. (L. Corkill): In introducing new pasture plants into commerce one has to make sure of the means by which the seed can be reproduced cheaply and easily. Have you had a look at this problem?

A. My problem is to produce the plant, not the seed. There could however be a problem for the seed producer as quite a number of plants have a long flowering season and there could be a lot of immature seed mixed with mature seed. For this reason selection of the parent material would have to be done very carefully. 